\title{
SYMPOSIUM ON B.S. CHIMNI, “CUSTOMARY INTERNATIONAL LAW: A THIRD WORLD PERSPECTIVE”
}

\section{A POSTMODERNIZATION OF CUSTOMARY INTERNATIONAL LAW FOR THE FIRST WORLD?}

\author{
Jean d'Aspremont*
}

In his recent piece in the American Journal of International Law, B.S. Chimni depicts a doctrine of customary international law that has allowed the First World to impose its domination and promote its version of global capitalist justice. ${ }^{1}$ From Chimni's perspective, all the gimmicks and sophisticated dichotomies invented by international lawyers to refine international customary law serve a hegemonic socialization process whereby the center imposes its neoliberal ideals on an admiring periphery. But this diagnosis is certainly not the end of the story. In fact, Chimni's dismal image of the world and the role of custom therein is meant to foreground a more central project-i.e., the reinvention of customary international law around "the progressive ideas, beliefs, and practices of the global civil society" and geared towards the promotion of the "common good." My view is that Chimni's postmodernization of the doctrine of international customary law does not necessarily remedy the charges he levels against custom, let alone redefine the center and the periphery. As much as I share his diagnosis about custom's complicity in hegemonic socialization and the promotion of a global capitalist ethos, I contend that Chimni's postmodernization $^{2}$ is at best unavailing and, at worse, rehabilitative of the First World's centrality in norm-setting. ${ }^{3}$ Instead of striving to reinvent the doctrine of custom, we must invest in strategies that draw on the malleability and fluidity of the current doctrine and facilitate the types of argumentation that "decenter" the First World, thereby directly empowering international lawyers elsewhere.

My argument is structured as follows. I first draw attention to some of the ambiguities in Chimni's otherwise compelling diagnosis. I then elaborate on my main contention, namely the incapacity of Chimni's postmodernization of custom to redefine the center and the periphery, and the possibility that postmodernization will serve the interests of the First World. I conclude with a few observations on what has long been my own project to address

\footnotetext{
* Professor of International Law, Sciences Po Law School and University of Manchester.

${ }^{1}$ B.S. Chimni, Customary International Law: A Third World Perspective, 112 AJIL 1 (2018).

2 Like Chimni, I refer to the "postmodernization" of custom as a move to redefine the doctrine of customary international law in a way that strips it of some of its modern trappings. Such usage is lacking in semantic and conceptual rigor, as I appreciate-following JeanFrançois Lyotard - that postmodernism is primarily a diagnosis, condition, or mindset rather than a method or an outlook. Yet, this loose and unrigorous use of "postmodernization" bears enough didactic virtues to justify a semantic sin.

${ }^{3}$ I refer to the "First World" rather than "the West," "capital-exporting states," or the "Global North." It is true that the expression "First World" carries the same unfortunate shortcuts, blind spots, and oversimplifications as the other labels. Yet, I believe the expression more explicitly acknowledges that the hegemony, global capitalist project, and neocolonial forces targeted by Chimni are not exclusively located in the West or the northern hemisphere.
}

The American Society of International Law and Jean d'Aspremont $(C$ 2018. This is an Open Access article, distributed under the terms of the Creative Commons Attribution licence (http://creativecommons.org/licenses/by/4.0/), which permits unrestricted reuse, distribution, and reproduction in any medium, provided the original work is properly cited. 
the hegemony of the First World in the sources of international law by promoting types of argumentation that deemphasize the practice and opinio juris of states located therein.

\section{A Modernist Diagnosis for a Postmodern Custom?}

Chimni's article shows the extent to which the doctrine of customary international law and all of its extras have been conducive to the imposition of the First World's global capitalist justice, not through crude force, but through specific modes of socialization that foster the internalization of ideas and beliefs by the periphery. The diagnosis is compelling. Yet the way in which he articulates it manages to rehabilitate some of the modern features of custom. Indeed, Chimni's depiction of custom reinforces the modern imaginary genealogy currently at work in international law by tracing back the dominant two-element doctrine of custom to Article 38 of the Statute of the Permanent Court of International Justice. As I have argued elsewhere, ${ }^{4}$ this genealogy obfuscates the actors who made the doctrine of custom yesterday (especially the Permanent Court of International Justice) and allows the actors who make custom today (especially the International Law Commission) to present their work as an interpretive exercise centered on Article 38. In that sense, Chimni perpetuates the continuous obfuscation of exercises of definitional power by those who actually design the fundamental doctrines through which international legal discourses are articulated and organized.

Chimni similarly perpetuates the modernism that accompanies the doctrine of customary international law by locating custom's foundation in pacta sunt servanda, which is one of the most common self-referential moves witnessed in modern international legal thought. Actually, by rooting the doctrine of customary international law in pacta sunt servanda, Chimni presupposes that states themselves create the modes of legal reasoning put in place by the sources of international law. Such a move not only oversimplifies the debate about the foundations of those sources and upholds the myth of state-centrism, but also perpetuates the modern distribution of powers in doctrine-making. This modernism suggests that Chimni's diagnosis of a hegemonic socialization through custom remains incomplete. Indeed, Chimni could have pushed his diagnosis further by engaging with the powerful institutions and individuals — mostly located in the First World — who have designed the way in which claims about customary law ought to be articulated and organized.

\section{A Postmodern Custom at the Service of a Rehabilitated Center?}

Chimni's diagnosis regarding customary international law remains convincing even if incomplete. Yet the therapy he envisages is less so. In particular, his proposed reinvention of the ascertainment of international customary law around "the progressive ideas, beliefs, and practices of the global civil society" and the "common good"what he calls the postmodernization of custom-is unlikely to overturn the hegemonic socialization that comes with modern custom and its promotion of global capitalist justice. In my view, Chimni's postmodernization would do little to rein in the sources of the First World's hegemony and its global capitalist justice. Interestingly, Chimni recognizes that more structural determinants may be at work. Yet, for him, a postmodernization of customary law can "help introduce important reforms in the international legal order" 5 and remedy Western and capitalist hegemony. Said differently, Chimni contends that changes in the global capitalist order and the definition of the center and the periphery can be brought about by changes in the doctrine of customary international law. This is where I respectfully dare to disagree.

\footnotetext{
${ }^{4}$ Jean d'Aspremont, The Decay of Modern Customary International Law in Spite of Scholarly Heroism, in Global Community Y.B. InT'L L. \& Juris. 9 (Giuliana Ziccardi Capaldo ed., 2015).

${ }^{5}$ Chimni, supra note 1 , at 38 .
} 
Most fundamentally, Chimni's assertion of a causal link between doctrinal postmodernization and effective resistance to First World hegemony strikes me as not only posited and unexplained, but also quite implausible. The modes of legal reasoning pertaining to the ascertainment of customary rules being only a tiny aspect of the hegemonic processes at work in international society, the reform of such modes seems unlikely to bring about major practical change. As long as the structural determinants of the First World's hegemony remain in place, I cannot see how postmodernization can effectively decenter the First World and deemphasize the practice and opinio juris of states located therein.

One could push this point even further. It is not only that Chimni's postmodernization may be futile, but also that it could intensify the grip of the First World on the identification of custom. In a world where half of the population is overconnected and overopinionated and the other half disconnected and in need of freedom of expression, food, and water, a custom that is ascertained through "progressive ideals, beliefs, and practices in the global society" will most likely remain a product of the First World. In other words, if the means of producing ideas, beliefs, and practices about what the common good can possibly be are not reallocated, merely shifting emphasis to those ideas, beliefs, and practices still leaves their initial production with those who have the material means to intervene-namely, the custom-making elite from the First World. In this way, Chimni's postmodernization most likely upholds the current distribution of custom-making powers, and thus the primacy of the current center at the expense of its admiring periphery.

\section{Argumentative Empowerment Rather Than a Postmodernization of Custom}

If, as I have argued so far, Chimni's postmodernization of customary international law is likely to prove unable to redefine the center and the periphery, the question becomes whether any realistic therapy remains. In this portion of the essay, I argue that the remedy to Chimni's diagnosis lies not in doctrinal reform, but rather in the empowerment of those on the periphery who could potentially make use of standard modes of legal reasoning in the identification of custom.

The doctrine of customary international law and the modes of legal reasoning that it puts in place are contradictory, inconsistent, indeterminate, and informal. ${ }^{6}$ These characteristics are in some respects problematic, but they also create enough space to empower anyone invoking custom, whether in the First World or elsewhere, to pursue their own vision of the international rule of law. In other words, the fluidity and malleability of the doctrine allows the identification of custom to operate both as a tool of oppression by the First World and as an empowerment of the periphery.

Drawing on the elasticity of both constitutive elements of custom, ${ }^{7}$ the undeniable material limitations related to the uneven production and dissemination of practice and opinio juris can be surmounted through an argumentation that deemphasizes the practice and opinio juris of those located in the First World. Indeed, the argumentative space currently available under the doctrine of customary international law is rather wide, and thus allows one to calibrate the weight assigned to the practice and opinio juris of different types of actors. For instance, there has hardly been any need for interpreters and judges to justify the selection of the particular states on whose practices they tend to focus, in part because the doctrine of specially affected states has proven to be quite ductile. Likewise, interpreters and judges have rarely shown great rigor, comprehensiveness, or systematicity with respect to the collection of evidence of practice and opinio juris, let alone the geographical distribution of such evidence.

\footnotetext{
${ }^{6}$ See Jean d'Aspremont, Customary International Law as a Dance Floor: Part II, EJIL: TALk! (Apr. 15, 2014).

${ }^{7}$ The recent work of the International Law Commission on the identification of customary international law has confirmed this elasticity. See Int'l Law Comm'n, Identification of Customary International Law: Text of the Draft Conclusions as Adopted by the Drafting Committee on Second Reading, UN Doc. A/CN.4/L.908 (May 17, 2018).
} 
And this is not to mention the immense creativity that we have witnessed in relation to the "finding" of opinio juris, which can also be manipulated and for which linguistic barriers no longer seem unsurmountable. ${ }^{8}$ As a general matter, the deemphasizing and decentering argumentation that I propose here would certainly not be unprecedented, as illustrated by the common move of international courts to deemphasize scientific controversies by recasting them according to legal categories. ${ }^{?}$

To be sure, the use of an argumentation that takes advantage of the indeterminacy of the doctrine of customary international law is not the end of the story. Some critical obstacles remain. The empowerment that I advocate requires access to the global arena of international legal argumentation. It also requires the means to engage in decentering argumentation and make one's position known globally. The material obstacles that currently affect the production and dissemination of practice and opinio juris may also surface in the production of a decentering and deemphasizing argumentation.

The question, then, is how to foster the material conditions that might facilitate such argumentation. One necessary step is to embolden international lawyers outside the First World to take advantage of custom's malleability and fluidity. This concretely means bringing an end to the complacent teachings that present the sources of international law as establishing determinate, stable, and formal law-ascertainment criteria that facilitate an "objective" distinction between law and nonlaw. In my view, those teachings constitute a grave form of neocolonialism. In particular, spreading a flat and mechanical image of the doctrine of customary international law prevents international lawyers outside the First World from taking advantage of custom's amorphous nature, and confines them to the periphery as long as such an image is not accompanied by counter-images that disrupt custom-ascertainment's stability, determinacy, and formalism. In this regard, I cannot help stressing the grave complicity of mainstream textbooks on international law. In my view, those textbooks perform a neocolonial function outside the First World when they are disseminated without any critical counterpoints that emphasize custom's flexibility. The global distribution of these textbooks from the First World subdues international lawyers outside the First World and maintains them in a peripheral status.

Yet, doing away with neocolonial tools such as textbooks is not sufficient. To facilitate a use of customary law that deemphasizes the practice and opinio juris of those located in the First World, one also needs to embark on the global promotion of a critical spirit that makes international lawyers across the globe well-versed in (and well-aware of) the argumentative space opened by custom's malleability and fluidity. This means, for instance, raising awareness about the possible use of the persistent objector doctrine in a way that contests the application of those customary rules that have coalesced in (and for) the First World, and shedding light on the possibility to construct opinio juris and practice that deemphasize states located in the First World.

This is where Chimni and I find ourselves most at loggerheads: whereas he favors a postmodernization of the sources, I favor an argumentative empowerment that takes advantage of the flexibility of those sources. The latter, as I see it, has the advantage of plausibility: ending the subjection of international lawyers outside the First World to flat and uncritical representations of custom while raising awareness of the doctrine's flexibility provide more plausible remedies to the complicity of the current doctrine in perpetuating a hegemonic center. It is only by facilitating the types of argumentation that have the potential to decenter the First World that one can seriously empower international lawyers elsewhere.

\footnotetext{
${ }^{8}$ One common example is the conflation of official statements with state practice. I have elaborated on this elsewhere. See Jean d'Aspremont, Customary International Law as a Dance Floor (Part I), EJIL: TALK! (Apr. 14, 2014); d'Aspremont, supra note 6.

${ }^{9}$ Jean d'Aspremont \& Makane Mbengue, Strategies of Engagement with Scientific Fact-Finding in International Adjudication, 5 J. INT'L Disp. Settlement 240 (2014).
} 